A History of Linear Electric Motors 
Other Macmillan titles of related interest

W. A. Atherton From Compass to Computer-A history of electrical and electronics engineering

J. D. Edwards Electrical Machines-An introduction to principles and characteristics 


\section{A History of \\ Linear Electric Motors}

Eric R. Laithwaite

$\mathrm{PhD}$, DSc, CEng, FIEE, FIEEE

Professor of Heavy Electrical Engineering

Imperial College, London

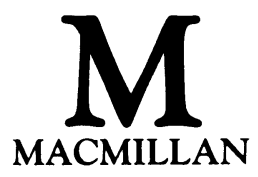




\section{(c) Eric R. Laithwaite 1987}

Softcover reprint of the hardcover 1st edition 1987 978-0-333-39928-6

All rights reserved. No reproduction, copy or transmission of this publication may be made without written permission.

No paragraph of this publication may be reproduced, copied or transmitted save with written permission or in accordance with the provisions of the Copyright Act 1956 (as amended).

Any person who does any unauthorised act in relation to this publication may be liable to criminal prosecution and civil claims for damages.

First published 1987

Published by

MACMILLAN EDUCATION LTD

Houndmills, Basingstoke, Hampshire RG21 2XS

and London

Companies and representatives

throughout the world

Distributed in the USA and Canada by

San Francisco Press, Inc.

Box 6800, San Francisco

CA $94101-6800$

Typeset by

TecSet Ltd, Sutton, Surrey

British Library Cataloguing in Publication Data

Laithwaite, E. R.

A history of linear electric motors.

1. Electric motors, Linear-History

I. Title

621.46'2 TK2537

ISBN 978-1-349-08298-8

ISBN 978-1-349-08296-4 (eBook)

DOI 10.1007/978-1-349-08296-4 


\section{Contents}

$\begin{array}{ll}\text { Preface ix } & \text { ix }\end{array}$

Acknowledgements $x$

1 Introduction-the first age of topology 1

1.1 Design and evolution 2

1.2 The earliest rotating machines 3

1.3 An explanation of some terminology 4

1.4 'Magnetic' and 'electromagnetic' machines 5

1.5 De mortuis nil nisi bonum 6

1.6 Fundamental shapes 8

1.7 A classification of machine shapes 9

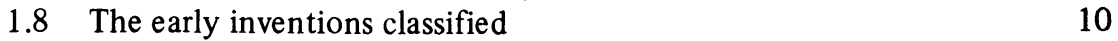

1.9 An engine should look like an engine! $\quad 12$

1.10 Steps forward and backward 21

1.11 Shape becomes an end in itself 26

1.12 1888-the biggest milestone since 1831

1.13 References 29

Appendix: Chronological order of rotating machine inventions 30

2 The early inventors and their patents 31

2.1 The pre-induction motor period 31

2.2 A.c. reciprocating motors 34

2.3 The start of the induction motor era 35

2.4 Boucherot, Zehden and Birkeland 36

2.5 Bachelet and World War I 38

2.6 Japolsky 41

2.7 Liquid metal pumps 43

$\begin{array}{ll}2.8 \text { World War II } & 45\end{array}$

2.9 References $\quad 50$ 
3 The contributions of the textile men $\quad 52$

3.1 'Action at a distance' is the 'bait' $\quad 52$

3.2 How a power loom weaves 53

3.3 The amazing Monsieur Jacquard 55

$\begin{array}{lll}3.4 & \text { Classifying shuttle drives } & 56\end{array}$

$\begin{array}{lll}3.5 & \text { A topological giant } & 57\end{array}$

3.6 Classification using electrical considerations 58

$\begin{array}{lll}3.7 & \text { A curiosity } & 59\end{array}$

$\begin{array}{lll}3.8 & \text { Milestones revealed by the patent history } & 61\end{array}$

$\begin{array}{ll}\text { 3.8.1 Concerning Monsieur Bachelet } & 61\end{array}$

3.8.2 The men who had it didn't know they had it 62

3.9 Duplication of effort 66

$\begin{array}{ll}3.10 \text { Ingenuity continues } & 67\end{array}$

3.11 An amateur textile engineer tries his hand 68

$\begin{array}{ll}3.12 \text { A naturally self-oscillating motor } & 70\end{array}$

$\begin{array}{ll}3.13 \text { Series and parallel worlds } & 76\end{array}$

3.14 The 'DNA' molecule of machine engineering 76

$\begin{array}{ll}3.15 \text { References } & 78\end{array}$

Appendix: Chronological order of patents on electromagnetic textile
devices

4 'Fashions' in engineering $\quad 84$

4.1 The task of the engineer $\quad 84$

4.2 The importance of 'fringe subjects' 84

4.3 Ignorance really is bliss! 85

4.4 Digression on a theoretical dilemma $\quad 85$

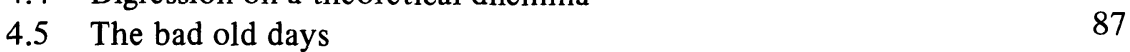

$\begin{array}{lll}4.6 & \text { A 'fashiongraph' } & 87\end{array}$

4.7 Extrapolation of the fashiongraph $\quad 88$

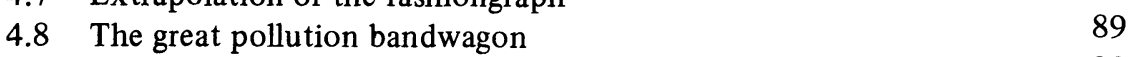

4.9 The danger of breeding a race of robots 90

4.10 Contrasts in industrial outlook 90

4.11 'We must simplify the theory' 90

4.12 Useful theory or formal discipline? 91

4.13 Unification for its own sake 91

4.14 Industrial 'pros and cons' 92

4.15 Automation $\quad 92$

4.16 Design or evolution? 93

4.17 Accountants become fashionable as dictators 93

4.18 References 94

5 Electromagnetic levitation $\quad 95$

$\begin{array}{lll}5.1 \text { Different worlds } & 95\end{array}$

$\begin{array}{lll}5.2 & \text { Obsession with cylindrical geometry } & 97\end{array}$

5.3 A theory 'brought out and dusted' 98 
$\begin{array}{lll}5.4 & \text { Levitation melting } & 102\end{array}$

$\begin{array}{lll}5.5 & \text { Levitation with a degree of freedom } & 104\end{array}$

$\begin{array}{lll}5.6 & \text { References } & 106\end{array}$

6 Academics and industrialists $\quad 107$

$\begin{array}{lll}6.1 \text { Background } & 107\end{array}$

$\begin{array}{lll}6.2 & \text { Portrait of an academic } & 108\end{array}$

$\begin{array}{ll}\text { 6.3 The importance of a great industrialist } & 110\end{array}$

$\begin{array}{lll}6.4 & \text { The new generation } & 112\end{array}$

$\begin{array}{ll}6.5 \text { John Lowe } & 112\end{array}$

$\begin{array}{ll}\text { 6.6 The 'clean-up' men } & 113\end{array}$

$\begin{array}{ll}\text { 6.7 The blending of electronics and 'machines' } & 116\end{array}$

6.8 A lot depended on communication 120

$\begin{array}{ll}6.9 \text { Series connection } & 122\end{array}$

$\begin{array}{ll}6.10 \text { References } & 123\end{array}$

7 The high-speed transport game $\quad 125$

$\begin{array}{ll}7.1 \text { What to leave out, not what to put in! } & 125\end{array}$

$\begin{array}{lll}7.2 & \text { The railway experiments } & 125\end{array}$

$\begin{array}{ll}7.3 \text { The 'Aérotrain' } & 130\end{array}$

7.4 The formation of Tracked Hovercraft Limited 134

$\begin{array}{lll}7.5 & \text { The pace makers } & 136\end{array}$

$\begin{array}{ll}7.6 \text { The long pole pitch problem } & 140\end{array}$

$\begin{array}{lll}7.7 & \text { The 'darkest hour before the dawn' } & 144\end{array}$

7.8 The three-part problem concept of the mid '60s 149

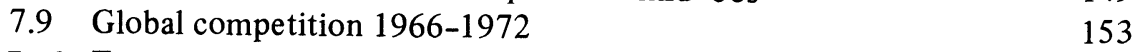

$\begin{array}{lll}7.10 & \text { Transpo } 72 & 160\end{array}$

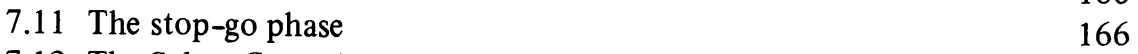

$\begin{array}{ll}7.12 \text { The Select Committee } & 167\end{array}$

$\begin{array}{ll}7.13 \text { References } & 168\end{array}$

8 The world-wide game $\quad 169$

$\begin{array}{ll}\text { 8.1 New readers begin here! } & 169\end{array}$

$\begin{array}{ll}\text { 8.2 The Toronto Urban Transit Scheme } & 170\end{array}$

$\begin{array}{lll}8.3 \text { Earith and after } & 172\end{array}$

$\begin{array}{ll}\text { 8.4 The Consortium of British Universities } & 175\end{array}$

$\begin{array}{ll}8.5 \text { 'Landspeed' } & 178\end{array}$

8.6 The world scene up to 1976, country-by-country 179

$\begin{array}{ll}\text { 8.6.1 USA } & 180\end{array}$

$\begin{array}{ll}\text { 8.6.2 Canada } & 187\end{array}$

$\begin{array}{ll}\text { 8.6.3 Japan } & 188\end{array}$

$\begin{array}{ll}\text { 8.6.4 Europe } & 190\end{array}$

8.6.5 USSR 194

$\begin{array}{lll}8.7 & \text { References } & 195\end{array}$ 
9 The second age of topology 196

$\begin{array}{ll}9.1 \text { A voice from the past } & 196\end{array}$

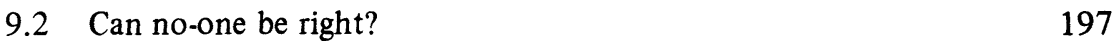

$\begin{array}{lll}9.3 & \text { The lateral dimension } & 197\end{array}$

9.3.1 Concern about stability and about power factor 200

$\begin{array}{lll}9.4 & \text { Tubular motors } & 202\end{array}$

9.5 The vertical dimension 205

9.5.1 Electromagnetic levitation 206

9.5.2 The topology of track joints $\quad 209$

$\begin{array}{ll}9.6 & \text { The longitudinal direction } \\ & 212\end{array}$

9.6.1 Surface current topology 213

$\begin{array}{ll}\text { 9.6.2 Superimposed skewed windings } & 215\end{array}$

$\begin{array}{lll}9.7 & \text { Linear synchronous motors } & 220\end{array}$

9.7.1 Claw-pole motors $\quad 220$

9.7.2 Combined cryogenic Maglev and propulsion $\quad 222$

$\begin{array}{lll}9.8 & \text { References } & 223\end{array}$

10 A continuing story $\quad 224$

$\begin{array}{lll}10.1 \text { General } & 224\end{array}$

10.2 'Stop-press' on HSGT 225

10.2.1 USA 226

$\begin{array}{ll}\text { 10.2.2 Canada } & 226\end{array}$

$\begin{array}{ll}10.2 .3 \text { Japan } & 226\end{array}$

10.2.4 West Germany $\quad 226$

10.2.5 UK 226

$\begin{array}{ll}10.3 \text { What have we learned? } & 229\end{array}$

$\begin{array}{ll}\text { 10.3.1 Wisdom } & 229\end{array}$

$\begin{array}{ll}10.3 .2 \text { Courage } & 229\end{array}$

10.3.3 Theory, design and evolution $\quad 230$

$\begin{array}{ll}10.3 .4 \text { Invention } & 231\end{array}$

$\begin{array}{lll}10.4 & \text { References } & 233\end{array}$

$\begin{array}{ll}\text { Bibliography } & 234\end{array}$

General $\quad 235$

Industrial applications $\quad 255$

$\begin{array}{ll}\text { Levitation } & 277\end{array}$

$\begin{array}{ll}\text { Transport } & 296\end{array}$

$\begin{array}{ll}\text { Theory } & 349\end{array}$

$\begin{array}{ll}\text { Index } & 385\end{array}$ 


\section{Preface}

The manuscript of this book was first prepared at the request of the Institution of Electrical Engineers in 1971. This coincided with a period of great activity in one particular aspect of linear motors, that of high-speed ground transport (HSGT) applications. It was a time when the Tracked Hovercraft project showed such great promise, when new inventions grew like mushrooms and hopes for a world-adopted British system ran high, only to be dashed by the Government's closure of the project in 1973 and demolition of the full-scale track in 1974. It was a time when personal emotions ran high.

The original draft contained a whole chapter on the rise and fall of Tracked Hovercraft, some of which was found unacceptable in that it might have given grounds for libel action. The whole manuscript was in fact revised to avoid giving any offence whatsoever. Meanwhile, new developments in HSGT were taking place in several countries from the USA to Japan and more papers were flooding in to swell the bibliography. By 1975 new papers on linear motors were appearing at the rate of between 14 and 16 per month and it was decided to close the bibliography at that date on the grounds of space and of the escalating task of crossreferencing to check that the bibliography after 1975 was complete.

Originally it had been intended to publish in 1983 with the final chapter bringing everything up to date, but the final manuscript was declined by the IEE's publishers in 1984 and a re-revision took place for the present publishers.

Some updating has been carried out on the last chapter in view of the time that has elapsed since the original target date for publication. Perhaps future historians may record that not until 1986 could the linear motor be said to have really become industrially accepted, for the author was invited to address the IEE in London on January 15, 1986 on the subject of 'Linear motors-a new species takes root', which was then to be published in Electronics and Power. In newspaper language and in the context of this book, this paper must surely be classed as 'Stop Press'!

Eric R. Laithwaite 


\section{Acknowledgements}

This work might never have been completed had it not been for the untiring efforts of my secretary, Miss Elizabeth Boden, who not only typed and re-typed the manuscript several times but corrected spelling and grammar and did a tremendous job on the bibliography in respect of accuracy and attention to detail. While neither of us pretends that it is now perfect, all I would say is that as the result of her efforts, 'It's a lot better than it was!'

I am also much indebted to Dr Brian Bowers of the Science Museum, South Kensington, firstly for help with research on the early days of the subject and the patents of Wheatstone in particular, and secondly for reading the whole manuscript and advising me on the production of a revised version that would offend no-one.

I am also grateful to the publishers for picking up the pieces when, at one time, all seemed a lost cause.

The diagrams were drawn by Mr E. Lawler. 